\title{
Estimating tree canopy water use via xylem sapflow in an old Norway spruce forest and a comparison with simulation-based canopy transpiration estimates
}

\author{
Barbara Köstner*, Eva M. Falge, Martina Alsheimer, \\ Ralf Geyer, John D. Tenhunen
}

Bayreuth Institute for Terrestrial Ecosystem Research (BITÖK), Department of Plant Ecology II, University of Bayreuth, 95440 Bayreuth, Germany

(Received 15 January 1997; accepted 20 October 1997)

\begin{abstract}
Tree xylem sapflow rates of 140-year-old Norway spruce (Picea abies) were scaled to the stand level and compared to canopy transpiration predicted by the stand gas exchange model STANDFLUX. Variation in sapflux densities between individual sensors was high (coefficient of variance $=0.4$ ) and included both variation within and between trees, but it was not different between two applied sapflow methodologies (radial flowmeter according to Granier, variable heating tissue heat balance method according to Cermák and Kucera). During the morning, a time-lag of typically $2 \mathrm{~h}$ elapsed between sapflow $\left(E_{\mathrm{f}}\right)$ and predicted canopy transpiration rate $\left(E_{\mathrm{p}}\right)$. During this time total water use was as high as $0.3 \mathrm{~mm}$, which was less than the estimated capacity of easily available water in the tree canopy $(0.45 \mathrm{~mm}$, on average $14 \mathrm{~L}$ per tree). Canopy conductance derived from stand sapflow rates $\left(g_{\mathrm{f}}\right)$ and from STANDFLUX $\left(g_{\mathrm{p}}\right)$ was in the same range $\left(g_{\text {tmax }}: 10 \mathrm{~mm} \mathrm{~s}^{-1}\right)$, but a stronger decline with increasing vapor pressure deficit of the air
\end{abstract}

* Correspondence and reprints

Abbreviations: $\mathrm{CBH}$ : tree circumference at breast height; $\mathrm{CV}$ : coefficient of variation; $\mathrm{DBH}$ : tree diameter at breast height; $D$ : vapor pressure deficit of the air; $D_{\max }$ : daily maximum half-hour average vapor pressure deficit of the air; $D_{\text {dark }}$ : average vapor pressure deficit during night; dw: dry weight; $E_{\mathrm{c}}$ : forest canopy transpiration rate; $E_{\mathrm{f}}$ : forest canopy transpiration rate derived with time shift in xylem sapflow; $E_{\mathrm{p}}$ : forest canopy transpiration rate predicted from STANDFLUX Model; $g_{\mathrm{c}}$ : canopy conductance; $g_{\mathrm{f}}:$ total conductance derived from shifted xylem sapflow; $g_{\mathrm{n}}$ : total conductance derived from non-shifted xylem sapflow; $g_{\mathrm{p}}$ : canopy conductance predicted from STANDFLUX model; $g_{\mathrm{t}}$ : total conductance from canopy to measurement height of $D ; g_{\text {tmax }}$ : maximum total canopy conductance; $J$ : sapflux density (sapflow rate per sapwood area); LAI: projected canopy leaf area index; LS: total leaf surface; LW: leaf dry weight; PPFD: photosynthetic photon flux density; SD: standard deviation; SE: standard error; $\mathrm{SWA}_{\mathrm{bh}}$ : sapwood area at breast height; $\mathrm{SWA}_{\mathrm{blc}}$ : sapwood area below live crown; SWV: sapwood volume. 
$(D)$ was observed for $g_{\mathrm{f}}$ as compared to $g_{\mathrm{p}}$ with current model parameterization. Tree water uptake measured by xylem sapflow was higher during spring and somewhat lower during summer compared with $E_{\mathrm{p}}$. Seasonal sums of transpiration from April to October amounted to 108 and $103 \mathrm{~mm} \mathrm{season}^{-1}$ for $E_{\mathrm{f}}$ and $E_{\mathrm{p}}$, respectively. Estimated tree water uptake during night increased with $D$ up to $0.5 \mathrm{~mm}$ per dark period (on average $16 \mathrm{~L}$ per tree) which was $10-140 \%$ of total daily flux. Because this flow rate did not increase with further increases in $D$ during night, it is concluded that it reflects the refilling of easily exchangeable water in the trees rather than a rate of night transpiration. (C Inra/Elsevier, Paris.)

forest transpiration / forest conductance / night water uptake / stand gas exchange model / Picea abies

Résumé - Estimation de la consommation en eau des arbres à partir de la mesure du flux de sève brute dans un peuplement âgé d'épicéa, et comparaison avec un modèle de transpiration du couvert. Les mesures de flux de sève brute réalisées dans un peuplement d'épicéa (Picea abies) âgé de 140 ans ont été extrapolées à l'échelle du peuplement et comparées à la transpiration du couvert prédite par le modèle Standflux. La variabilité des densités de flux entre les mesures individuelles était élevée (coefficient de variation de 0,4 ), liée aussi bien à la variabilité intraarbre qu'interarbres, mais les mesures ne différaient pas entre les deux méthodes utilisées (fluxmètre radial de Granier, et bilan d'énergie à chaleur variable de Cermak et Kucera). Au cours de la matinée, un déphasage, atteignant typiquement $2 \mathrm{~h}$, se produisait entre le flux de sève $\left(E_{\mathrm{f}}\right)$ et la transpiration prédite $\left(E_{\mathrm{p}}\right)$. L'équivalent en eau correspondait à $0,3 \mathrm{~mm}$ pour cette durée, ce qui est inférieur à la quantité d'eau facilement disponible dans le couvert des arbres $(0,45 \mathrm{~mm}$, soit en moyenne $14 \mathrm{~L}$ par arbre $)$. La conductance de couvert, calculée à partir des mesures de flux de sève du peuplement $\left(g_{\mathrm{f}}\right)$ et du modèle Standflux $\left(g_{\mathrm{p}}\right)$, étaient du même ordre de grandeur $\left(g_{\text {tmax }}: 10 \mathrm{~mm} \mathrm{~s}-1\right)$, mais une décroissance plus forte, en relation avec l'augmentation du déficit de saturation de l'air $(D)$, était observée pour $g_{\mathrm{f}}$ comparé à $g_{\mathrm{p}}$, avec la paramétrisation actuelle du modèle. La consommation en eau par les arbres mesurée à partir du flux de sève était plus élevée au printemps, et relativement plus faible en été, par rapport à $E_{\mathrm{p}}$. Les cumul saisonniers de transpiration entre avril et octobre ont atteint $108 \mathrm{~mm}$ saison $^{-1}$ et $103 \mathrm{~mm}$ saison $^{-1}$ pour $E_{\mathrm{f}}$ et $E_{\mathrm{p}}$, respectivement. La consommation en eau par les arbres durant la nuit augmentait avec D jusqu'à $0,5 \mathrm{~mm}$ par nuit (soit en moyenne $16 \mathrm{~L}$ par arbre), ce qui correspondait à 10 à $140 \%$ du flux total journalier. Comme ce flux n'augmentait pas notablement au-delà d'un certain seuil de $D$ pendant la nuit, il a été conclu que ce flux reflétait plus le remplissage du réservoir d'eau facilement échangeable des arbres plutôt qu'une véritable transpiration nocturne. (C Inra/Elsevier, Paris.)

transpiration de la forêt / conductance / absorption hydrique nocturne / modèle de transpiration / Picea abies

\section{INTRODUCTION}

Tree xylem sapflow rates scaled to the stand level provide an independent estimate of forest water use which can be referred to above canopy water vapor flux to separate the contribution of trees from other components $[8,20,21,31]$. Tree transpiration estimated with a dry canopy and added to a careful estimate of the forest floor component [56] sums to values close to total system evapotranspiration [3]. In intensively managed forest ecosystems which show a patchy mosaic of stands varying in age and structure, such as the Lehstenbach catchment in our study [1], comparisons of old forest canopy water use with water vapor fluxes measured by eddy covariance are difficult due to the small surface occupied by the old forest stands in the catchment and because the understory contribution is large. Dur- 
ing 1994, water vapor fluxes from the forest floor and from patches of the understory vegetation (Deschampsia flexuosa, Calamagrostis villosa, Vaccinium myrtillus) in a 140-year-old Norway spruce stand were estimated by lysimeters and chamber gas exchange techniques [57]. On summer days, areally integrated water vapor fluxes below the tree canopy reached values of up to $1.1 \mathrm{~mm} \mathrm{~d}^{-1}$ which equalled ca $40 \%$ of total stand water loss.

Furthermore, tree water storage changes in large trees during periods when transpiration is observed via sapflow or at the leaf level [11, 44]. Storage changes dynamically on a daily basis $[10,25,47]$ as well as on a seasonal basis as continuous depletion and recharge of water content in the trees occurs from spring to winter in correlation with soil drying and wetting $[6,54,55]$. While diurnal changes in tree water storage depend on a relatively small pool of easily available water in extensible tissues, seasonal changes in water content are related to the total amount of extractable water in woody tissues [53].

In the following, we compare canopy water use estimated by xylem sapflow methods with canopy transpiration predicted by a three-dimensional gas exchange model STANDFLUX [13, 15]. STANDFLUX uses information on threedimensional tree structure and temporal variation in the profile of atmospheric factors to calculate spatial light interception and process-based gas exchange of threedimensional canopy units. Estimates of stand xylem sapflow and modelled canopy transpiration are used to 1) investigate principle differences in the water uptake and canopy transpiration at various temporal scales, 2) compare estimates of canopy conductance derived from both approaches, and 3) estimate tree water uptake during the night in relation to total canopy transpiration.

\section{MATERIALS AND METHODS}

\subsection{Study site and sample tree characteristics}

The study sites is located in the Lehstenbach catchment in the Fichtelgebirge (Northeast Bavaria/Germany; latitude $50^{\circ} 9^{\prime} \mathrm{N}$, longitude $11^{\circ} 52^{\prime} \mathrm{E}$ ) which comprises an area of ca $4 \mathrm{~km}^{2}$ with altitudinal variation from $877 \mathrm{~m}$ a.s.l. at the Waldstein summit to $700 \mathrm{~m}$ at the discharge weir. About $90 \%$ of the catchment is covered with Norway spruce (Picea abies (L.) Karst.) varying in age from young regrowth to stands up to 160 years [36]. Average annual temperatures typically range between 5 and $6.5^{\circ} \mathrm{C}$ and annual precipitation between 950 and 1050 $\mathrm{mm}$. A relatively high number of foggy days (100-200 per year) and a short vegetation period is typical for the region ([40]; for general infomation on climate of the Fichtelgebirge, see also Eiden [12]).

Six stands ranging in age from 40 to 140 years were chosen for transpiration studies [1]. In this paper, data from the oldest site (Coulissenhieb) are presented. Characteristics of sample trees used for sapflow measurements are shown in table $\mathrm{l}$; for stand characteristics see table II. Stand density and stand basal area were determined for all 803 trees within the study area ( 2.5 ha; Gerstberger, unpublished). Leaf biomass (LW), total leaf surface (LS) and sapwood area below live crown $\left(\mathrm{SWA}_{\mathrm{blc}}\right)$ were determined by harvest of five trees $\left(\mathrm{LW}(\mathrm{kg})=27.56^{*} \mathrm{CBH}(\mathrm{m})^{2.51}\right.$, $r^{2}=0.96 ; \mathrm{LS}\left(\mathrm{m}^{2}\right)=347.9^{*} \mathrm{CBH}(\mathrm{m})^{2.35}, r^{2}=$ $0.95 ; \mathrm{SWA}_{\mathrm{blc}}\left(\mathrm{m}^{2}\right)=0.017 * \mathrm{CBH}(\mathrm{m})^{1.83}, r^{2}=$ 0.97; Köstner and Fischer, unpublished). Total leaf surface was converted to projected leaf area by division of 2.57 [39]. The average relation of $\mathrm{SWA}_{\mathrm{blc}} / \mathrm{SWA}$ was 0.52 (cf. 0.5 for Douglas fir in [54]), the average relation of tree height $\mathrm{blc}_{\mathrm{blc}}$ /total height of 25 trees was 0.58 . Due to the relatively low cumulative sapwood area of the 140-year-old stand, the leaf area/sapwood area ratio was highest at this site as compared to the younger sites in the catchment [1]. Sapwood area at breast height $\left(\mathrm{SWA}_{\mathrm{bh}}\right.$ ) was determined by two or three stem cores on 45 trees and by stem disks from the five harvested trees $\left(\mathrm{SWA}_{\mathrm{bh}}\left(\mathrm{m}^{2}\right)=\right.$ $\left.0.032 * \mathrm{CBH}(\mathrm{m})^{1.98}, r^{2}=0.82 ; n=50\right)$. Values from stem disks agreed with average values from stem cores. Good agreement between 
methods was also found using computer tomography for non-destructive determination of total sapwood area of the trees [1]. Cumulative sapwood area of the stand was determined by the equation above using the $\mathrm{CBH}$ of all trees $(n=803)$ from the site.

\subsection{Meteorological data}

Meteorological data were obtained from a $30 \mathrm{~m}$ telescopic mast [30] located within the stand. Photosynthetic photon flux density (PPFD) was measured at the top of the mast

Table I. Biometric data from sample trees $(n=13)$ measured during 1995 at the 140 -year-old stand Coulissenhieb.

\begin{tabular}{lcccc}
\hline $\begin{array}{l}\text { Biometry of sample } \\
\text { trees }(n=13)\end{array}$ & Mean & SD & Min & Max \\
\hline DBH $(\mathrm{m})$ & 0.39 & 0.08 & 0.27 & 0.53 \\
CBH $(\mathrm{m})$ & 1.23 & 0.24 & 0.84 & 1.65 \\
Basal area $\left(\mathrm{m}^{2}\right)$ & 0.12 & 0.05 & 0.06 & 0.22 \\
Total height $(\mathrm{m})$ & 26.6 & 2.4 & 23.0 & 31.0 \\
Height & 14.5 & 2.2 & 9.5 & 18.0 \\
Proj. needle area $\left(\mathrm{m}^{2}\right)$ & 231 & 105 & 90 & 440 \\
Needle mass $(\mathrm{kg})$ & 49.0 & 23.7 & 17.8 & 96.6 \\
SWA $_{\text {bh }}\left(\mathrm{m}^{2}\right)$ & 0.049 & 0.019 & 0.022 & 0.086 \\
SWA $_{\text {blc }}\left(\mathrm{m}^{2}\right)$ & 0.025 & 0.009 & 0.012 & 0.042 \\
$\mathrm{SWV}_{\text {blc }}\left(\mathrm{m}^{3}\right)$ & 0.54 & 0.03 & 0.16 & 1.15 \\
\hline
\end{tabular}

Crown biomass data were calculated from CBH of the sample trees by equations (see text) derived from five trees harvested in 1992 (Köstner and Fischer, unpublished).

Table II. Stand characteristics of the 140-year-old stand Coulissenhieb determined from either all 803 trees of the site (tree density, $\mathrm{CBH}$ ), from 50 selected trees $\left(\mathrm{SWA}_{\mathrm{bh}}\right)$ or 25 trees (tree height, height ${ }_{b \mid c}$ ).

\begin{tabular}{|c|c|}
\hline & Stand charateristics \\
\hline Stand age & 140 \\
\hline Tree density (trees ha ${ }^{-1}$ ) & 320 \\
\hline Mean tree height (m) & 25 \\
\hline Mean tree height ${ }_{\mathrm{blc}}(\mathrm{m})$ & 14.5 \\
\hline Mean tree diameter $(\mathrm{m})$ & 0.37 \\
\hline Cumulative basal area $\left(\mathrm{m}^{2} \mathrm{ha}^{-1}\right)$ & 35.3 \\
\hline Cumulative $\mathrm{SWA}_{\mathrm{bh}}\left(\mathrm{m}^{2} \mathrm{ha}^{-1}\right)$ & 14.0 \\
\hline Cumulative $S W A_{b l c}\left(\mathrm{~m}^{2} \mathrm{ha}^{-1}\right)$ & 7.2 \\
\hline $\mathrm{SWV} \mathrm{V}^{\mathrm{blc}}\left(\mathrm{m}^{3} \mathrm{ha}^{-1}\right)$ & 154 \\
\hline Needle dry weight ( $\mathrm{tha}^{-1}$ ) & 13.6 \\
\hline Proj. leaf area index & 6.5 \\
\hline
\end{tabular}

Crown biomass data were calculated from $\mathrm{CBH}$ of all 803 trees by equations (see text) derived from five harvested trees (Köstner and Fischer, unpublished). 
with linearized photodiodes (G1118, Hamamatsu) calibrated against a LiCor quantum sensor (Li 190SB, LI-COR, Inc., Lincoln, Nebraska, USA). Air humidity, air temperature and wind speed were measured at three heights $(30,17$ and $1 \mathrm{~m})$ using VAISALA HMP-35 UTA humidity sensors (Vaisala, Finland) with linearized thermistors and threedimensional anemometers (ONZ-Windmesser, MeteolaborAG, Wetikon, Switzerland) with high resolution propellers (YOUNG, Traverse City, Michigan, USA). Data from $30 \mathrm{~m}$ height were used as driving variables for the STANDFLUX model and to analyse dependencies of stand sapflow on environmental variables. Vapor pressure deficit $(D)$ was calculated using the MAGNUS formula [7] with constants from Smithsonian Meteorological Tables [50]. Standard meteorological data were also provided by the Department of Climatology (BITÖK, University Bayreuth; Gerchau, unpublished).

\subsection{Xylem sapflow}

Xylem sapflow of eight trees was measured by an electronically controlled constant temperature difference system (tissue heat balance system, THB) constructed according to Cermák and co-workers $[5,35]$. Sapflux density $(J)$ of five additional trees was measured by constant heating flowmeters according to Granier $[18,19]$. The flux signals were measured every $10 \mathrm{~s}$ and $10-\mathrm{min}$ averages were stored by a data logger. The sensors of the constant temperature difference system covered the average sapwood depth $(4 \mathrm{~cm})$ while sensors of the constant heating system covered $2 \mathrm{~cm}$ of sapwood depth. No significant change in $J$ measured in different depths $(0-2,2-4 \mathrm{~cm})$ was observed during the season. Sapflux density of the THB system was calculated by dividing tree xylem sapflow by estimated sapwood area of the tree. Maximum $J$ of individual measurements was in the same range for both methods (figure 1). Accordingly, no systematic difference was found between methods on a daily basis [1].

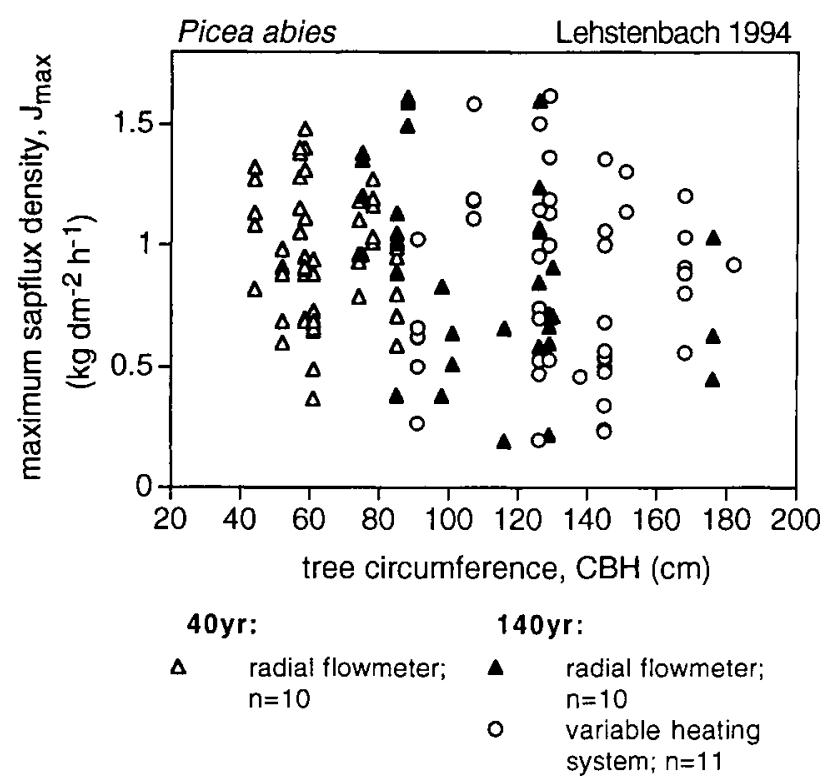

Figure 1. Range of maximum half-hourly sapflux densities in relation to tree $\mathrm{CBH}$ measured by the radial flowmeter according to Granier and the variable heating system according to Cermák and Kucera on five dry summer days in 1994 at a 40- and 140-year-old Norway spruce site in the Lehstenbach catchment. 


\subsection{Scaling from tree to stand level}

For scaling sapflow measurements from sensor to forest stand xylem sapflow rates are related to structural scalars of the trees or stand. Due to high variation at the sensor level (see below), we calculated mean $J$ from non-stratified samples and used cumulative sapwood area of the stand (cumul. SWA $\mathrm{bh}_{\mathrm{b}}$ ) to derive forest canopy transpiration $\left(E_{f}\right)$ :

$E_{\mathrm{f}}=$ mean $J_{\text {sample trees }}{ }^{*}$ cumul. SWA $\mathrm{Ahh}_{\mathrm{bh}}$

Variation in $J$ of all forest sites measured in the catchment was high and independent from tree size of codominant or emergent trees (figure 2 ). This high variation in $J$ was referred to within tree variation in sapwood distribution, sapwood density or activity (highest ratio of two sensor records within one tree at breast height $=1: 3$ ), and between tree variation in tree size or leaf area. For a selection of five summer days with mean $J$ ranging between 0.08 and $0.11 \mathrm{~kg} \mathrm{~cm}^{-2} \mathrm{~d}^{-1}$ and a number of 55-58 codominant and emergent sample trees measured in the catchment, the coefficient of variation $(\mathrm{CV})$ ranged between 0.41 and 0.46 independent of sapflow methodologies. According to the corresponding $t$-value (twosided), e.g. $t_{55: 0.05}$ the sample size required for a $C V$ of $15 \%$ would amount to $30-38$ while a usual sample size of between 11 and 9 trees corresponds to a CV of 25 to $30 \%$. Oren et al. [38] report sample sizes from 7 to 48 of various tree species for a required $\mathrm{CV}$ of $15 \%$. A relative deviation of \pm 15 and $22 \%$ from the mean was determined for 12 sample trees of old Scots pine and old Norway spruce [4].

\subsection{Estimation of canopy conductance from stand sapflow}

Canopy conductance derived from sapflow measurements comprises the total water vapor transfer conductance $\left(g_{1}\right)$ from the 'average' stomata of the tree canopy to the measurement height of $D$ [52], which includes both aerodynamic ( $g_{\mathrm{a}}$ : components of momentum and surface boundary layer; e.g. [27]) and stomatal components $\left(g_{\mathrm{c}}\right)$. It follows: $1 / g_{\mathrm{t}}=1 / g_{\mathrm{c}}+1 / g_{\mathrm{a}}$, see Köstner et al. [32]. Because $g_{a}$ is usually an order of magnitude larger than $g_{c}$ in coniferous stands, $E_{\mathrm{c}}$ is controlled by $g_{\mathrm{c}}$ rather than by $g_{\mathrm{a}}$ and, therefore, differences between $g_{\mathrm{t}}$ and $g_{c}$ are small.

To account for the delay of sapflow rates compared to transpiration rates, the onset of stand sapflow $\left(E_{\mathrm{f}}\right)$ was simply fitted as a first approximation to the onset of predicted transpiration $\left(E_{\mathrm{p}}\right)$ which corresponded to the onset of irradiance (PPFD $>25 \mu \mathrm{mol} \mathrm{m}^{-2} \mathrm{~s}^{-1}$ ) on dry days. Total canopy conductance was calculated from sapflow as follows [32]:

$$
g_{\mathrm{f}}=k * E_{\mathrm{f}} / D
$$

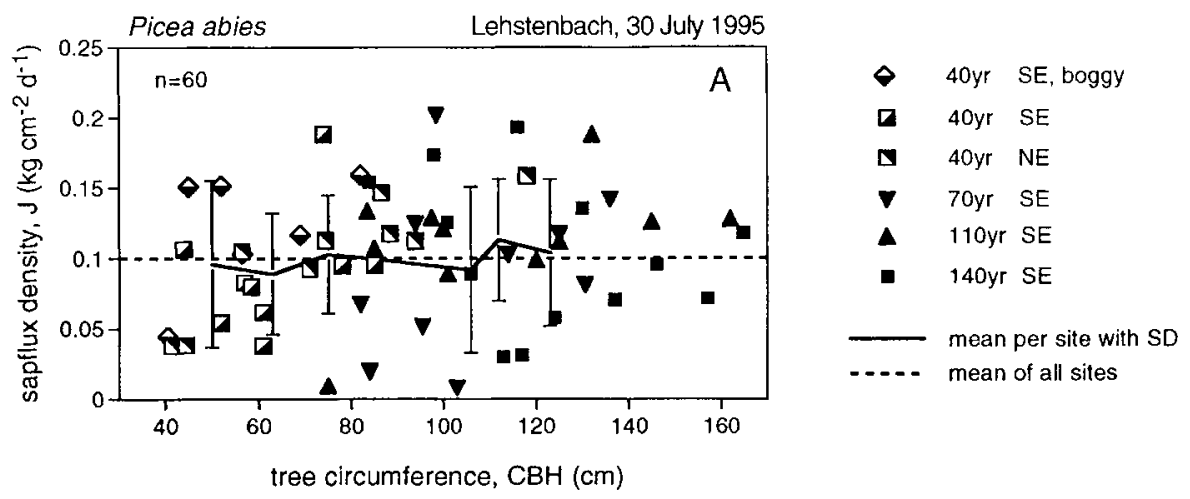

Figure 2. Variation of daily mean sapflux densities in relation to tree circumference $(\mathrm{CBH})$ of 60 sample trees measured on 30 July 1995 at six different sites of the Lehstenbach catchment. 
Conversion factor $k=G_{\mathrm{v}} * T_{\mathrm{K}} ; G_{\mathrm{v}}=$ gas constant of water vapor $\left(4.62 \mathrm{~m}^{3} \mathrm{hPa} \mathrm{kg}^{-1} \mathrm{~K}^{-1}\right)$, $T_{\mathrm{K}}=$ air temperature (Kelvin); values of $D<1$ $\mathrm{hPa}$ were excluded.

\subsection{The STANDFLUX model}

The STANDFLUX model $[13,15]$ integrates three-dimensional information on stand structure and vertical information on stand microclimate to compute spatial light interception and spatial canopy gas exchange. It consists of three nested components with a leaf or branch gas exchange module [14], a threedimensional single-tree light interception and gas exchange module, and the resulting threedimensional forest stand gas exchange model.

Gas exchange of foliage elements is described according to Harley and Tenhunen [24] based on estimates of leaf carboxylation, RuBP regeneration and respiratory capacities $[16,17]$, and an empirical formulation for leaf conductance [2]. The application to needled branch segments is described in Falge et al. [14]. Stomatal conductance is calculated as:

$g_{\mathrm{s}}=\underset{* h_{\mathrm{s}}}{g_{\min }}+\operatorname{gfac}_{\mathrm{s}} * 1000 *\left(\mathrm{NP}+0.5 R_{\mathrm{d}}\right)$

with net $\mathrm{CO}_{2}$ fixation rate, $\mathrm{NP}\left(\mu \mathrm{mol} \mathrm{m} \mathrm{m}^{-2} \mathrm{~s}^{-1}\right)$, relative humidity, $h_{\mathrm{s}}$ (decimal fraction), $\mathrm{CO}_{2}$ partial pressure, $C_{\mathrm{\varsigma}}(\mathrm{ppm})$, empirically determined minimum conductance, $g_{\min }\left(\mathrm{mmol} \mathrm{m}{ }^{-2}\right.$ $\mathrm{s}^{-1}$ ), and gfac (dimensionless), describing the empirically determined sensitivity of stomata to changes in NP, $h_{\mathrm{s}}$ and $C_{\mathrm{s}}$ [51]. Leaf conductance in subsections was scaled to the canopy by leaf area of subsections and tree classes, defined by similarity in size, structure and physiology, and based on structural measurements at the site $[13,15]$. A boundary layer conductance $\left(g_{\mathrm{a}}\right)$ is considered per canopy subsection, estimated according to Nobel [37], modified for conifers as suggested by Jarvis et al. [28] and adopted to the given leaf area distribution in the canopy subsection [15]. From total canopy conductance $\left(g_{\mathrm{p}}\right)$ canopy transpiration was calculated by multiplying $g_{\mathrm{p}}$ with $D$ measured above the canopy [see equation (2)]:

$$
E_{\mathrm{p}}=g_{\mathrm{p}} * D / k
$$

\section{RESULTS AND DISCUSSION}

Daily courses of $E_{\mathrm{c}}$ and $g_{\mathrm{t}}$ derived from different approaches are compared in figure 3 . While $E_{\mathrm{p}}$ increased strongly with photosynthetic photon flux density (PPFD), the course of $E_{\mathrm{f}}$ was more similar to the course of vapor pressure deficit of the air $(D)$ (figure $3 A, B$ ). A time-lag of typically about $2 \mathrm{~h}$ on dry days elapsed between the onset of PPFD or $E_{\mathrm{p}}$ and $E_{\mathrm{f}}$. This time-lag is related to the contribution to transpiration of easily available water extracted from extensible tissue of needles, bark and young xylem $[9,42,45$, $53,59]$. Rapid diurnal depletions of water are mainly related to changes in water content of the crown biomass, while seasonal depletions of stored water can be observed in the stem $[6,54,55]$.

For the old spruce stand, a potential amount of $9 \mathrm{~mm}(280 \mathrm{~L}$ per tree) extractable water in the stem $\mathrm{blc}_{\mathrm{c}}\left(154 \mathrm{~m}^{3}\right.$ $\mathrm{ha}^{-1} \mathrm{SWV}_{\mathrm{blc}} * 0.6$, for conversion of total SWV into available water according to Waring and Running [54]) and $2 \mathrm{~mm}$ (sum of water content in needles and branches) in the crown biomass is estimated. About $0.45 \mathrm{~mm}$ (on average $14 \mathrm{~L}$ per tree) of the crown pool would be easily available water (assuming $120 \%$ rel. water content of needle dry mass, $80 \%$ rel. water content of branch dry mass and $10 \%$ of total water content as easily extractable water; see table II for biomass estimates). Time-lags between leaf transpiration and water flow sensed in the xylem are determined by tissue storage capacity while hydraulic resistences influence the flux rate (e.g. [29]). Higher hydraulic resistances are usually observed in branches compared to the stem of Norway spruce [49]. Roberts [43] reported that hydraulic resistance of cut trees (Pinus sylvestris) placed in water pots was only half that of control trees with intact root systems. Further, contribution of water stored in the trunk to transpiration was less for the trees in 


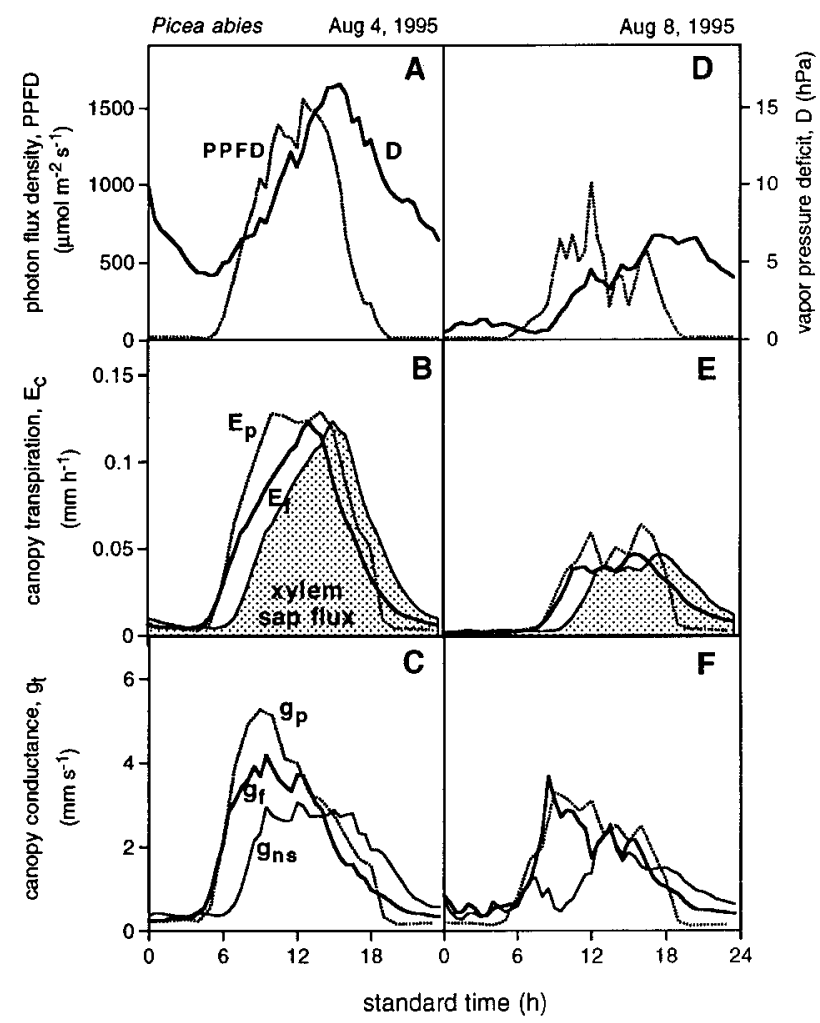

Figure 3. Daily courses of PPFD, $D$, measured and predicted canopy transpiration $\left(E_{\mathrm{f}}, E_{\mathrm{p}}\right)$, nonshifted stand xylem sapflux and estimates of conductance (see text) on a sunny (4 August) and cloudy (8 August) day in 1995 at the 140-year-old Norway spruce site.

water pots, obviously due to the lacking of root resistance. However, a temporary removal of stored water in the upper stem was also observable in the cut trees, suggesting that most easily available reservoirs of water are transpired first.

In our case, the sum of $E_{\mathrm{p}}$ during the first 2-3 h of summer days did not exceed $0.2-0.3 \mathrm{~mm}$ (on average 6-9 L per tree), which is less than the estimated amount of easily available water in the crown. There is no strong evidence that artificial time-lags of thermoelectric heat balance systems caused by heat storage in the stem
$[22,34,58]$ play an important role. The variable power input of the THB system as well as the low power input of the constant heating system are probably less sensitive to artificial thermal effects compared to systems which apply constant heat around the whole stem [23]. There was also no apparent difference between time-lags measured with the constant heating system and the variable heating system.

For calculation of canopy conductance from stand sapflow, the course of $E_{\mathrm{f}}$ was shifted to the onset of $E_{\mathrm{p}}$ (figure $3 B, E$ ). 
Conductance values derived from nonshifted $E_{\mathrm{f}}\left(g_{\mathrm{ns}}\right)$ result in significantly lower values during morning and midday (figure $3 C, F$ ). We are aware that simple shifting of the sapflow values cannot account for effects of internal water storage on canopy transpiration during the whole daily course. This would require direct measurements and appropriate modelling of changes in water content and potential gradients [10]. Since conductance derived from sapflow inherently includes stomatal, hydraulic and aerodynamic features, it should be understood as a particular, specific measure. Nevertheless, for a useful practical description good qualitative characteristics of $g_{f}$ are obtained in comparison to $g_{p}$ of the gas exchange model. Maximum values (see below) or values of higher temporal integration [41] are useful for comparative or complementary studies.
In figure 4 daily courses of $E_{\mathrm{f}}$ and $E_{\mathrm{p}}$ are shown for May and August 1995. Pronounced differences between measured and predicted values occurred during May. Water uptake of trees during spring could be referred to refilling of storage capacities $[54,55]$. In spring after rainy days up to 20 April, initial sapflow started with increasing temperature $\left(>20^{\circ} \mathrm{C}\right)$ and increasing $D(>15 \mathrm{hPa})$. During this period, sapflow did not reach zero during night compared to lowest or no apparent flux on cold $\left(<5^{\circ} \mathrm{C}\right)$ or rainy days in the middle of May. During August, hourly maxima of measured flux rates were lower than predicted ones while more similar flux rates were obtained during July. In August, sapflow rates sensed during nights with relatively high $D(10-15 \mathrm{hPa})$ did not reach minimum values as observed during rainy days.

Differences between $E_{\mathrm{f}}$ and $E_{\mathrm{p}}$ decreased with increasing temporal inte-
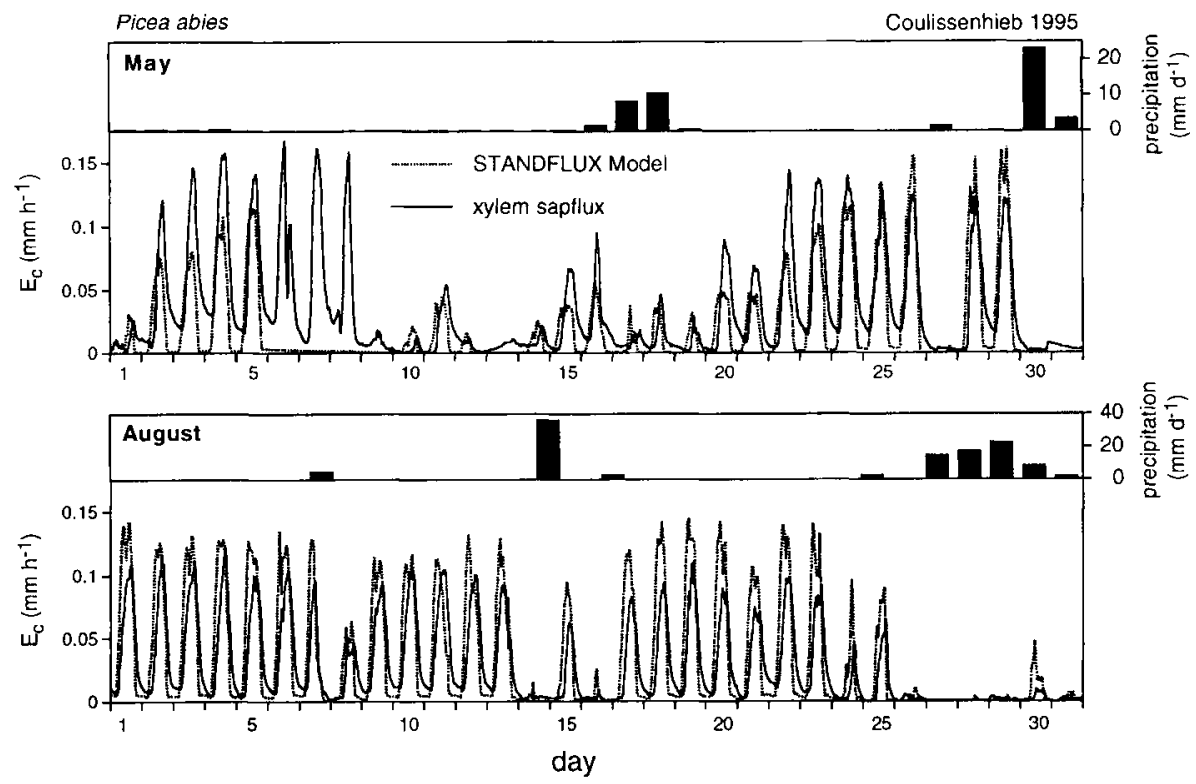

Figure 4. Comparison of daily courses of measured and predicted canopy transpiration $\left(E_{\mathrm{f}}, E_{\mathrm{p}}\right)$ during May and August 1995. Daily precipitation is indicated. 
gration of the data. While discrepancies remained quite large on a daily basis (figure $5 A$ ), differences declined on a monthly basis (figure $5 B$ ). High water uptake of trees measured by xylem sapflow during spring resulted in $26 \mathrm{~mm}$ month $^{-1}$ measured in May compared to $18 \mathrm{~mm} \mathrm{month}^{-1}$ predicted by the model. In contrast, $E_{\mathrm{f}}$ was slightly lower in August compared to $E_{\mathrm{p}}$ (21 and $25 \mathrm{~mm} \mathrm{month}^{-1}$ for measured and predicted values). Very similar estimates of $E_{\mathrm{c}}$ were obtained in June (13), July (28 and 29), September (8 and 7) and October $\left(4 \mathrm{~mm} \mathrm{month}^{-1}\right.$ for measured and predicted values, respectively). Over the whole season from April to October, $E_{\mathrm{c}}$ of both approaches agreed well but was generally relatively low (108 and $103 \mathrm{~mm}$ season ${ }^{-1}$ for measured and predicted values). Low rates of $E_{\mathrm{p}}$ resulted from low predicted light interception due to needle clumping in the modelled canopy sections. No seasonal changes in leaf physiology were included in the model and no drought effects were considered in the model prediction. There is no strong evidence that $E_{\mathrm{c}}$ was restricted by soil drought, although effects of increased soil resistance on tree water uptake during summer cannot be fully excluded. Maximum soil suction $(400-600 \mathrm{hPa})$ occurred for short periods in late July and August in the upper soil horizon $(20 \mathrm{~cm}$ depth) but remained low during the rest of the year $(<200 \mathrm{hPa})$, while soil suction never exceeded $100 \mathrm{hPa}$ in $90 \mathrm{~cm}$ depth (Lischeid, pers. comm.).

The relationship between $g_{\mathrm{t}}$ and $D$ derived from stand sapflow and predicted from STANDFLUX is shown in figure 6. Generally, $g_{t}$ from both approaches was in the same range. In some cases, higher tree water uptake measured by sapflow in May (cf. discussion on figure 4) resulted in higher maximum conductances compared to modelled conductance. Different responses of $g_{\text {tmax }}$ to $D$ between May and August are also explained by lower air temperature in May resulting in lower values of predicted photosynthesis and $g_{\mathrm{p}}$ in May for the same value of $D$ as compared to August. Daily mean temperature ranged from 2 to $17^{\circ} \mathrm{C}$ and from 13 to $21^{\circ} \mathrm{C}$ in
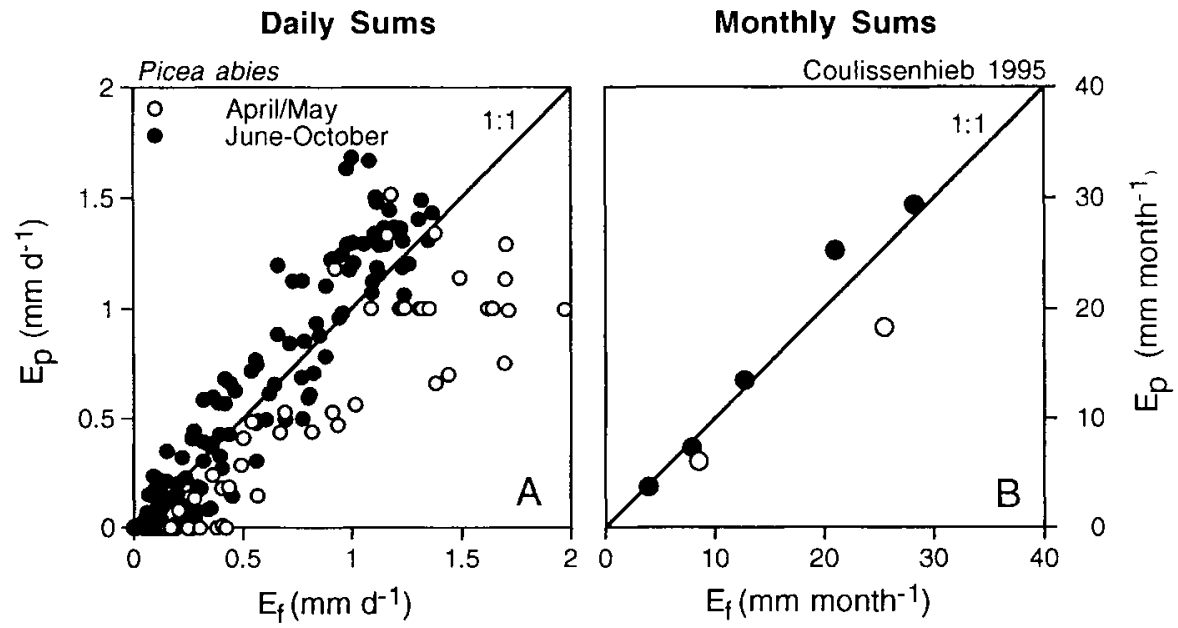

Figure 5. Correlation of daily (A) and monthly sums (B) of canopy transpiration of measured stand xylem sap flow $\left(E_{\mathrm{f}}\right)$ and predicted transpiration $\left(E_{\mathrm{p}}\right)$. 


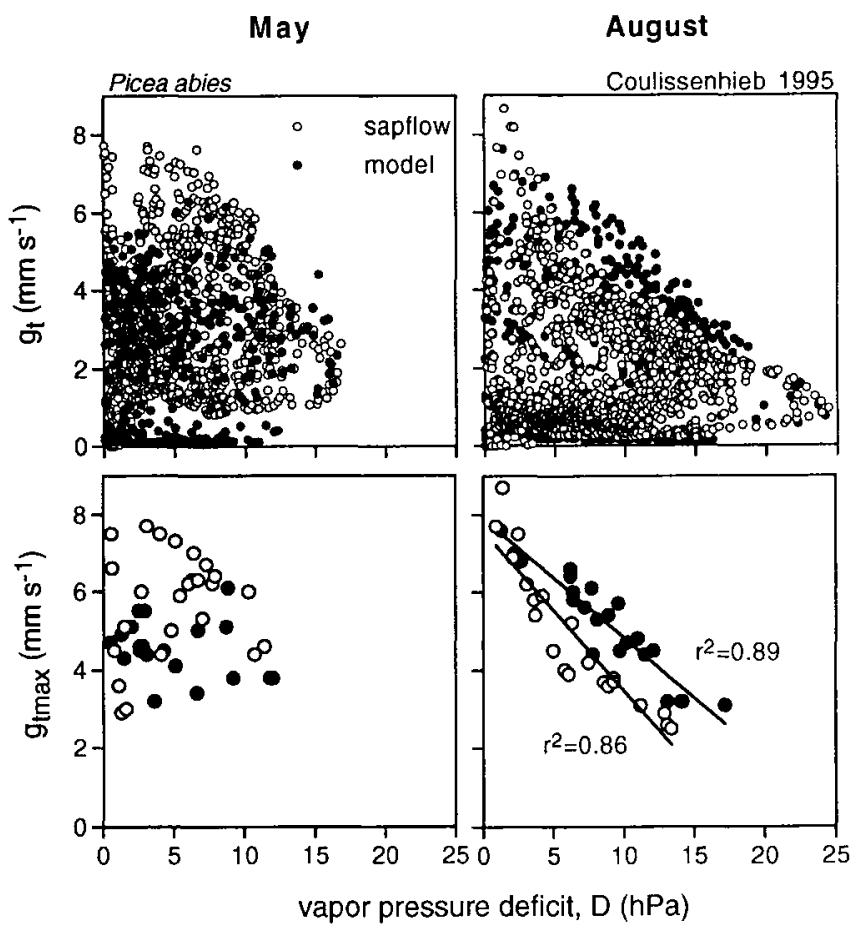

Figure 6. Hourly and maximum values of canopy conductance derived from xylem sapflow and STANDFLUX related to vapor pressure defict measured above the canopy for May and August 1995.

May and August, respectively. In August, $g_{\mathrm{f}}$ was more reduced with increasing $D$ than $g_{\mathrm{p}}$ showing a stronger curvilinear decline of $g_{f}$. Although the determination of canopy conductance from stand sapflow remains critical without correction of changes in capacity throughout the daily course (cf. discussion on figure $3 C, F$ ), the values are comparable to the range of values for Picea abies summarized by Schulze et al. [48].

During this study of old Norway spruce frequent sapflow was monitored during night $\left(E_{\text {dark }}\right)$. This water uptake is related to refilling of tissues and to transpiration during night when stomata are not completely closed. Predicted night transpiration of STANDFLUX, based on empirical estimates of minimum conductance $\left(g_{\text {min }}\right)$ [14] was not necessarily zero during the night but it was generally much less than measured sapflow during the night (see below). The amount of water taken up by trees during the dark period $\left(E_{\text {dark }}\right)$ was calculated for the different seasons by adding the flow rate from sunset to sunrise (defined as PPFD $<25 \mu \mathrm{mol} \mathrm{m} \mathrm{m}^{-2} \mathrm{~s}^{-1}$ ). Typical amounts of xylem sapflow during the night of dry summer days ranged between 0.2 and $0.4 \mathrm{~mm}$. $E_{\text {dark }}$ was posi- 
tively correlated with the total daily amount of $E_{\mathrm{f}}$ (figure $7 \mathrm{~A}$ ) but did not exceed a certain threshold (ca $0.5 \mathrm{~mm}$ ) in summer. Although, the estimation of $E_{\text {dark }}$ is critical owing to uncertainties of thermoelectric methods in determining the zero line of sapflux, the values of $E_{\text {dark }}$ are reasonable in relation to estimations of easily available water storage in extensible tissue. $E_{\text {dark }}$ was also correlated with increasing $D$ in the night ( $D_{\text {dark }}$ ) up to ca $5 \mathrm{hPa}$ but no further increase of $E_{\text {dark }}$ with increasing $D_{\text {dark }}$ was observed (figure $7 B$ ). The ratio of $E_{\text {dark }} / E_{\mathrm{f}}$ during dry summer days (for $E_{\mathrm{f}}>0.5 \mathrm{~mm} \mathrm{~d}^{-1}$ ) was on average $30 \%$ while low rates of $E_{\mathrm{f}}$ on rainy, foggy or cold days were associated with a high range of $E_{\mathrm{dark}} / E_{\mathrm{f}}$ values from 10 to $140 \%$ (figure $7 C$ ). However, the absolute amount of $E_{\text {dark }}$ was not related to the amount of precipitation indicating no strong effect of soil moisture on tree water uptake during the night. Under conditions of higher soil water depletion, rain events during the night may play a more important role in stem refilling [41]. Further, an increase of $g_{\text {fmax }}$ with increasing $E_{\text {dark }} / E_{\mathrm{f}}$ ratio was observed (figure $7 D$ ). The relationship also holds if $E_{\text {dark }} / E_{\mathrm{f}}$ is correlated to $g_{\text {umax }}$ of the following day. This demonstrates that the status of actual tree water storage could control maximum conductance reached during the day [53].
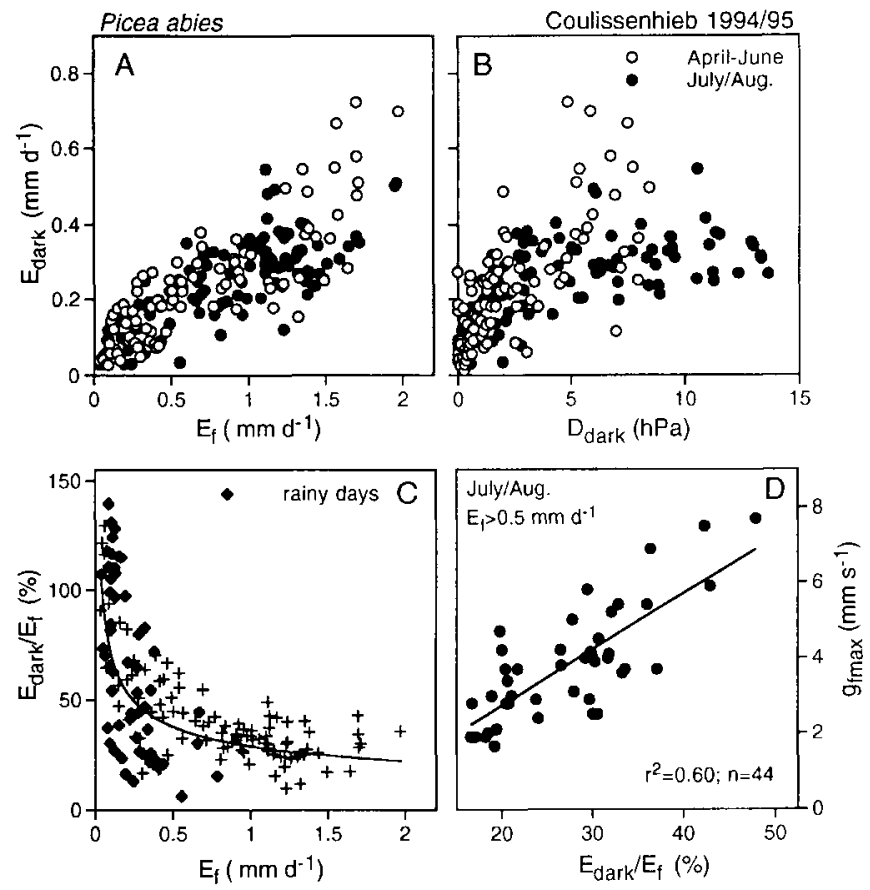

Figure 7. Correlation of stand sapflow rates measured during the dark period $\left(E_{\text {dark }}\right)$ with stand sapflow of the total day $\left(E_{\mathrm{f}} ; \mathrm{A}\right)$ and with average vapor pressure deficit of the dark period $\left(D_{\text {dark }}\right.$; $\mathrm{B}$ ); correlation of $E_{\mathrm{f}}$ with the ratio $E_{\mathrm{dark}} / E_{\mathrm{f}}(\mathrm{C})$ for spring and summer periods, and correlation of $E_{\text {dark }} / E_{\mathrm{f}}$ with $g_{\mathrm{f} \text { max }}$ for dry summer days (D). 


\section{CONCLUSIONS}

Tree sapflow rates scaled to the stand level and canopy transpiration predicted by a stand-level model based on canopy gas exchange were used to analyse principle differences in tree water uptake and canopy transpiration. Considering uncertainties in estimating stand sapflow both approaches agreed on a daily basis throughout the season. Relative differences between the approaches occurred over the season. We conclude that differences in spring are influenced by changes in tree water storage due to higher tree water uptake compared to canopy transpiration. On the other hand, model parameterization might not correctly reflect seasonal trends in leaf physiology.

Changes in tree water storage are also involved in estimating canopy conductance from stand sapflow compared to conductance derived from canopy photosynthesis. As a practical approximation the course of sapflow rates can be shifted to the onset of transpiration to obtain useful estimates of $g_{\mathrm{f}}$ comparable to predicted estimates. But because conductance from sapflow data inherently includes stomatal, hydraulic and aerodynamic features, it should be understood as a specific measure complementary to leaf or surface conductance.

In large trees water uptake was recorded during the entire night period indicating refilling of xylem and extensible tissues, and possible transpiration during the night. Because maximum water uptake during night increased with $D$, but was confined to a certain threshold (ca $0.5 \mathrm{~mm}$ ), we conclude that it indicates storage capacities rather than night transpiration. The high ratio of $E_{\mathrm{dark}} / E_{\mathrm{f}}$ (up to $50 \%$ ) during dry summer days stresses the importance of storage capacities. In future research more emphasis should be laid on the dynamics and quantification of storage capacities at the tree and stand level [10] and on the improvement of sapflow methodology monitoring water uptake during the night to investigate decoupling of bulk water flow in large trees from canopy water vapor flux driven by short-term changes in atmospheric conditions.

\section{ACKNOWLEDGEMENTS}

We thank A. Suske and G. Müller for their technical assistance and two reviewers for their helpful comments on the manuscript. Financial support was provided by the German Ministry for Research and Technology (BEO 51$0339476 \mathrm{~A}$ ) and the Bavarian Climate Research Program BayFORKLIM.

\section{REFERENCES}

(1) Alsheimer M., Köstner B., Tenhunen J.D., Canopy transpiration of Norway spruce stands (Picea abies [L.] Karst.): seasonal trends and stand differences, Ann. Sci. For. 55 (1998).

[2] Ball J.T., Woodrow I.E., Berry J.A., A model predicting stomatal conductance and its contribution to the control of photosynthesis under different environmental conditions, in: Binggins I. (Ed.), Progress in Photosynthesis Research, Vol IV.5, Proc. of the VII International Photosynthesis Congress, 1987, pp. 21-224.

[3] Bernhofer C., Gay L.W., Granier A., Joss U., Kessler A., Köstner B., Siegwolf R., Tenhunen J.D., Vogt R., The HartX-Synthesis: An experimental approach to water and carbon exchange of a Scots pine plantation, Theoret. Appl. Climatol. 53 (1-3) (1996) 173-183.

[4] Cermák J., Cienciala E., Kucerá J., Lindroth A. Bednárová, Individual variation of sapflow rate in large pine and spruce trees and stand transpiration: a pilot study at the central NOPEX site, J. Hydrol. 168 (1995) 17-27.

[5] Cermák J., Deml M., Penka M., A new method of sap flow determination in trees, Biol. Plant 15 (1973) 171-178.

16] Clark J., Gibbs R.D., Studies in tree physiology. IV. Further investigations of seasonal changes in moisture contents of certain Canadian forest trees, Can J. Botany 35 (1957) 219-253.

[7] Deutscher Wetterdienst (Ed.), AspirationsPsychrometer-Tafeln, 5, Auflg., Vieweg, Braunschweig, 1976.

[8] Diawara A., Loustau D., Berbigier P., Comparison of two methods for estimating the cvaporation of a Pinus pinaster (Ait.) stand: 
sap flow and energy balance with sensible heat flux measurements by an eddy covariance method, Agric. For. Meteorol. 54 (1991) 49-66.

[9] Dobbs R.C., Scott D.R.M., Distributions of diurnal fluctuations in stem circumference of Douglas fir, Can J. For. Res. 1 (1971) 80-83.

[10] Domec J.C., Bosc A., Loustau D., An analysis of the spatial variability of sap flow density in maritime pine, Ann. Sci. For. (1998).

[11] Edwards W.R.N., Jarvis P.G., Relations between water content, potential and permeability in stems of conifers, Plant Cell Environ. 5 (1982) $271-277$

[12] Eiden R., Air pollution and deposition, in: Schulze E.-D., Lange O.L., Oren R. (Eds.), Forest Decline and Air Pollution, Ecological Studies 77, Springer, Berlin, 1989, pp. 57-103.

[13] Falge E.M., Berechnung der Kronendachtranspiration von Fichtenbeständen (Picea abies (L.) Karst.) mit unterschiedlichen Modellierungsansätzen, thesis, University Bayreuth (1997).

[14] Falge E.M., Graber W., Siegwolf R., Tenhunen J.D., A model of the gas exchange response of Picea abies to habitat conditions, Trees 10 (1996) 277-287.

[15] Falge E.M., Ryel R.J., Alsheimer M., Tenhunen J.D., Effects of stand structure and physiology on forest gas exchange: A simulation study for Norway spruce, Trees 1 l (1997) 436-448.

[16] Farquhar G.D., von Caemmerer S., Modelling of photosynthetic response to environment, in: Lange O.L., Nobel P.S., Osmond C.B., Ziegler H. (Eds.), Water Relations and Carbon Assimilation, Encyclopedia of Plant Physiology, NS vol. 12B, Physiological Plant Ecology II, Springer, Berlin, 1982, pp. 549-587.

[17] Farquhar G.D., von Caemmerer S., Berry J.A., A biochemical model of photosynthetic $\mathrm{CO}^{2}$ assimilation in leaves of $\mathrm{C}_{3}$ species, Planta 149 (1980) 78-90.

[18] Granier A., Une nouvelle méthode pour la mesure du flux de sève brute dans le tronc des arbres, Ann. Sci. For. 42 (1985) 193-200.

[19] Granier A., Evaluation of transpiration in a Douglas-fir stand by means of sap flow measurements, Tree Physiol. 3 (1987) 309-320.

[20] Granier A., Biron P., Köstner B., Gay L.W., Najjar G., Comparisons of xylem sap flow and water vapour flux at the stand level and derivation of canopy conductance for Scots pine, Theoret. Appl. Climatol. 53 (1-3) (1996) 115-122.

[21] Granier A., Bobay V., Gash J.H.C., Gelpe J., Saugier B., Shuttleworth W.J., Vapour flux density and transpiration rate comparisons in a stand of Maritime pine (Pinus pinaster Ait.) in Les Landes forest, Agric. For. Meteorol. 51 (1990) 309-319.
[22] Grime V.L., Morison J.I.L., Simmonds L.P., Including the heat storage term in sap flow measurements with the stem heat balance method, Agric. For. Meteorol. 74 (1995) $1-25$.

123] Grime V.L., Morison J.I.L., Simmonds L.P., Sap flow measurements from stem heat balances: a comparison of constant with variable power methods, Agric. For. Meteorol., 74 (1995) 27-40.

[24] Harley P.C., Tenhunen J.D., Modeling the photosynthetic response of $C_{3}$ leaves to environmental factors, in: Boote K.J., Loomis R.S. (Eds.), Modeling Crop Photosynthesis - from Biochemistry to Canopy, ASA (Am. Soc. Agron. and Crop Science Society of America) Symposium, Madison, Wisconsin, 1991, pp. 17-39.

[25] Herzog K.M., Häsler R., Thum R., Diurnal changes in the radius of a subalpine Norway spruce stem: their relation to the sap flow and their use to estimate transpiration, Trees 10 (1995) 94-101.

[26] Hollinger D.Y., Kelliher F.M., Schulze E.D., Köstner B.M.M., Coupling of tree transpiration to atmopsheric turbulence, Nature 371 (1994) 60-62.

[27] Jarvis P.G., Coupling of carbon and water interactions in forest stands, Tree Physiol. 2 (1986) $347-368$.

[28] Jarvis P.G., James G.B., Landsberg J.J., Coniferous forest, in: Monteith J.L. (Ed.), Vegetation and Atmosphere Vol. 2, Case Studies, Academic Press, London, 1976, pp. 171-240.

[29] Jones H.G., Plants and Microclimate, 2nd ed., Cambridge University Press, Cambridge, 1992.

[30] Joss U., Graber W., Profiles and simulated exchange of $\mathrm{H}_{2} \mathrm{O}, \mathrm{O}_{3}, \mathrm{NO}_{2}$ between the atmosphere and the HartX Scots pine plantation, Theoret. Appl. Climatol. 53 (1996) 157-172.

[31] Kelliher F.M., Köstner B.M.M., Hollinger D.Y., Byers J.N., Hunt J.E., McSeveny T.M., Meserth R., Weir P.L., Schulze E.-D., Evaporation, xylem sap flow, and tree transpiration in a New Zealand broad-leaved forest, Agric. For. Meteorol. 62 (1992) 53-73.

[32] Köstner B.M.M., Schulze E.-D., Kelliher F.M., Hollinger D.Y., Byers J.N., Hunt J.E., McSeveny T.M., Meserth R., Weir P.L., Transpiration and canopy conductance in a pristine broadleaved forest of Nothofagus: an analysis of xylem sap flow and eddy correlation measurements, Oecologia 91 (1992) 350-359.

[33] Köstner B., Alsheimer M., Tenhunen J.D., Water fluxes in a spruce forest ecosystem: tree canopy transpiration at different sites, Verhandlungen der Gesellschaft für Ökologie 26 (1996) 61-68. 
[34] Köstner B., Granier A., Cermák J., Sapflow measurements in forest stands methods and uncertainties, Ann. Sci. For. 55 (1998) 13-27.

[35] Kucera J., Cermák J., Penka M., Improved thermal method of continual recording the transpiration flow rate dynamics, Biol. Plant 19 (1977) 413-420.

[36] Manderscheid B., Göttlein A., Wassereinzugsgebiet 'Lehstenbach' - das BITÖKUntersuchungsgebiet am Waldstein (Fichtelgebirge, NO-Bayern), Bayreuther Forum Ókologie 18 (1995) 84.

[37] Nobel P.S., Biophysical Plant Physiology and Ecology, W.H. Freeman and Company, San Francisco, 1983, p. 608.

[38] Oren R., Phillips N., Katul G., Ewers B.E., Pataki D.E., Scaling xylem sap flux and soil water balance, and calculation variance: a method for partitioning water flux in forests, Ann. Sci. For. 55 (1998) 191-216.

[39] Oren R., Schulze E.-D., Matyssek R., Zimmermann R., Estimating photosynthetic rate and annual carbon gain in conifers from specific leaf weight and leaf biomass, Oecologia 70 (1986) 187-193.

[40] Peters K., Gerchau J., Klima und luftchemische Situation des Fichtelgebirges unter besonderer Berücksichtigung des Einzugsgebietes Lehstenbach, in: Manderscheid B., Göttlein A. (Ed.), Wassereinzugsgebiet 'Lehstenbach' - das BITÖK-Untersuchungsgebiet am Waldstein (Fichtelgebirge, NO-Bayern), Bayreuther Forum Ökologie 18 (1995) 15-39.

[41] Phillips N., Oren R., A comparison of daily representations of canopy conductance based on two conditional time-averaging methods and the dependence of daily conductance on environmental factors, Ann. Sci. For. 55 (1998) 217-235.

[42] Roberts J., An examination of the quantity of water stored in mature Pinus sylvestris $\mathrm{L}$. trees, J. Exp. Bot. 27 (1976) 473-479.

[43] Roberts J., The use of tree-cutting techniques in the study of the water relations of mature Pinus sylvestris L, J. Exp. Bot. 28 (1977) 751-767.

[44] Running S.W., Relating plant capacitance to the water relations of Pinus contorta, For. Ecol. Manag. 2 (1980) 237-252.

[45] Running S.W., Waring R.H., Rydell R.A., Physiological control of water flux in conifers: a computer simulation model, Oecologia 18 (1975) 1-18.

[46] Schulze E.-D., The regulation of plant transpiration: interactions of feedforward, feedback, and futile cycles, in: Schulze E.-D. (Ed.), Flux Control in Biological Systems, Academic press, 1994, pp. 203-235.

[47] Schulze E.-D., Cermák J., Matyssek R., Penka M., Zimmermann R., Vasicek F., Gries W., Kucera J., Canopy transpiration and water fluxes in the xylem of the trunk of Larix and
Picea trees - comparison of xylem flow, porometer and cuvette measurements, Oecologia 66 (1985) 475-483.

[48] Schulze E.-D., Kelliher F.M., Körner C., Lloyd J., Leuning R., Relationships between plant nitrogen nutrition, carbon assimilation rate, and maximum stomatal and ecosystem surface conductances for evaporation: A global ecology scaling exercise, Ann. Rev. Ecol. System 25 (1994) 629-660.

[49] Sellin A.A., Hydraulic architecture of Norway spruce, Sov. Plant Physiol. 35 (1989) 839-845.

[50] Smithsonian Institution, Smithsonian Meteorological Tables, 6 th revised edition, Washington D.C., 1966.

[51] Tenhunen J.D., Hanano R., Abril M., Weiler E.W., Hartung W., Above- and belowground controls on leaf conductance of Ceanothus thyrsiflorus growing in a chaparral environment: The role of abscisic acid, Oecologia 99 (1994) 306-314

[52] Thom A.S., Momentum, mass and heat exchange of vegetation, Quart J. Roy. Met. Soc. 98 (1972) 124-134.

[53] Waring R.H., Running S.W., Water uptake, storage and transpiration by conifers: a physiological model, in: Lange O.L., Kappen L., Schulze E.-D. (Eds.), Water and Plant Life, Ecological Studies 19, Springer, Berlin, 1976, pp. 189-202.

[54] Waring R.H., Running J.W., Sapwood water storage: its contribution to transpiration and effect upon water conductance through the stems of old-growth Douglas-fir, Plant Cell Environ. 1 (1978) 131-140.

[55] Waring R.H.. Whitehead D., Jarvis P.G., The contribution of stored water to transpiration in Scots pine, Plant Cell Environ. 2 (1979) 309-317.

[56] Wedler M., Heindl B., Hahn S.C., Köstner B., Tenhunen J.D., Model-based estimates of water loss from 'patches' of the understory mosaic of the Hartheim Scots pine plantation, Theoret. Appl. Climatol. (1996) 135-144

[57] Wedler M., Köstner B., Tenhunen J.D., Water fluxes in a spruce forest ecosystem: estimates of forest understory evapotranspiration, Verhandlungen der Gesellschaft für Ökologie 26 (1996) 69-77.

[58] Weibel F.P., Boersma K., An improved stem heat balance method using analog heat control, Agric. For. Meteorol. 75 (1995) 191-208.

[59] Wronski E.B., Holmes J.W., Turner N.C., Phase and amplitude relations between transpiration, water potential and stem shrinkage, Plant Cell Environ. 8 (1985) 613-622. 